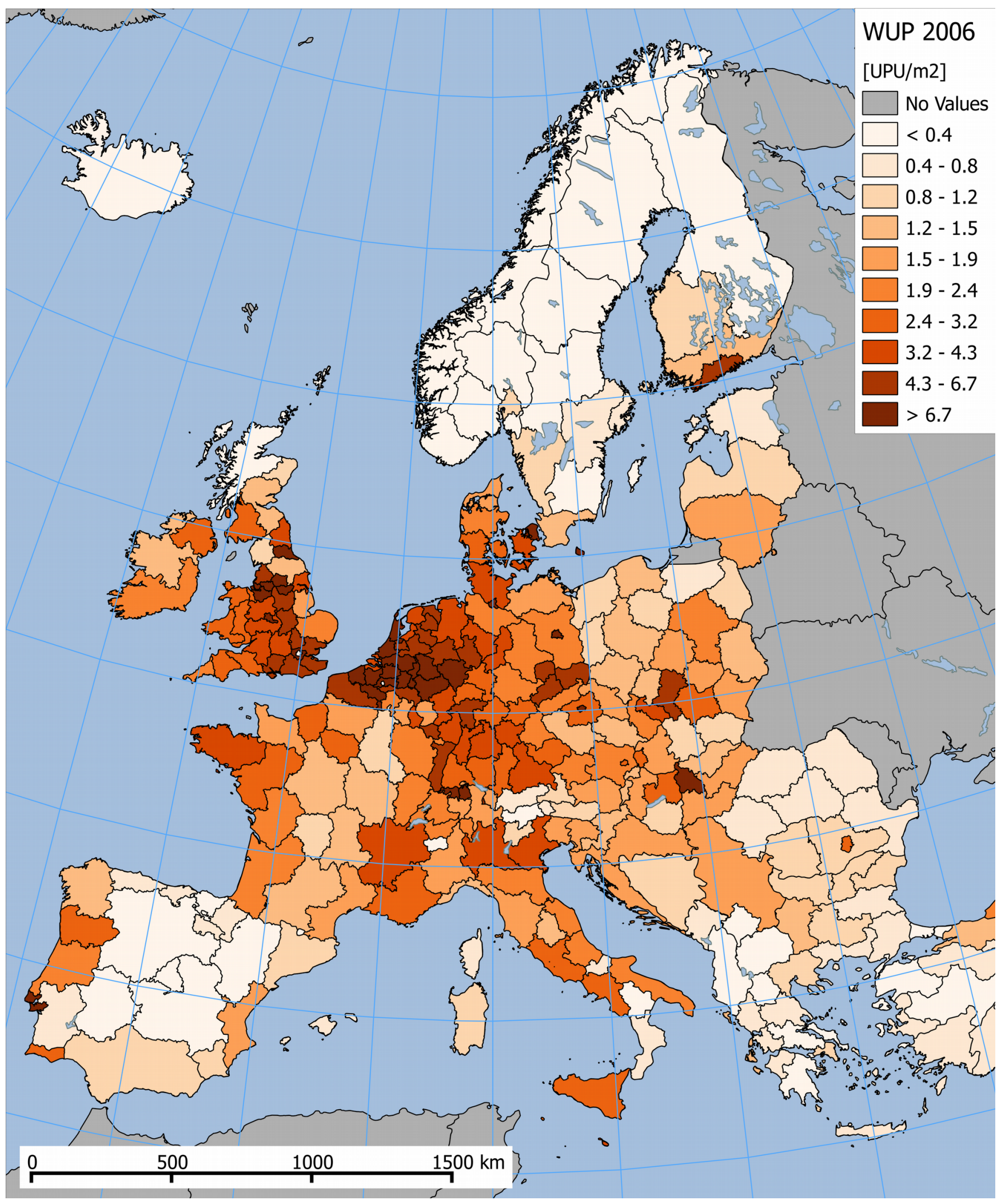




\title{
Multi-scale analysis of urban sprawl in Europe: Towards a European de-sprawling strategy
}

\author{
Ernest I. Hennig ${ }^{\mathrm{a}, *}$, Christian Schwick ${ }^{\mathrm{b}}$, Tomáš Soukup ${ }^{\mathrm{c}}$, Erika Orlitovác ${ }^{\mathrm{c}}$, Felix Kienast ${ }^{\mathrm{b}}$, Jochen A.G. Jaeger ${ }^{\mathrm{a}, * *}$ \\ ${ }^{a}$ Department of Geography, Planning and Environment, Concordia University, Montréal, Quebéc, Canada \\ ${ }^{b}$ Swiss Federal Research Institute WSL, Birmensdorf E ETH Zürich, Switzerland \\ ${ }^{c}$ GISAT and the European Center of Land Use and Spatial Information (ETC-LUSI) of the European Environmental Agency, Prague, Czech \\ Republic
}

\begin{abstract}
Urban sprawl is a major challenge on the way to sustainable land use as highlighted by the International Year of Soils 2015. Because of increasing awareness of this threat in Europe, there is an urgent need to monitor urban sprawl and to guide European policy development. We found considerable sprawl in Europe at three scales with highly affected regions in the center and along the Mediterranean coast using recently available consistent data across Europe from the European Copernicus programme. Based on our results, we propose a European de-sprawling strategy, including the implementation of targets and limits, and a set of concrete measures to control urban sprawl and to use land in a more resource-efficient way.
\end{abstract}

Keywords: landscape metrics, Weighted Urban Proliferation (WUP), NUTS-2 regions, urban development, de-sprawling strategies

\footnotetext{
This document is a collaborative effort.

*Corresponding author

** Principal corresponding author

Email addresses: ernest.hennig@interia.eu (Ernest I. Hennig), jochen. jaeger@concordia.ca (Jochen A.G. Jaeger)
} 


\section{Introduction}

The global human population will further increase by $30-70 \%$ in this century, and will lead to a population shift from rural to urban areas and to significant land-uptake for urban expansion (Montgomery, 2008; Gerland et al., 2014; United Nations, 2014). The need for both more food production and urban development will fuel the conflict between 5 each, i.e., the need for locations with valuable soils and for suitable construction ground. For example, the Food and Agricultural Organization of the United Nations (FAO) expects an increase of $43 \%$ in global food demand by 2030 (Food and Agriculture Organization of the United Nations (FAO), 2011). While this competition is pronounced in continents with the strongest population increase, i.e., Africa and Asia (Lambin et al., 2001; Chen, 2007; United Nations, 2014), it is also strong in other regions where more land is taken for urban areas because of higher land-uptake per person and increasing dispersion of built-up areas (Eigenbrod et al., 2011).

Western and Central Europe are among the most densely populated regions (106 persons $/ \mathrm{km}^{2}$ in 2005 ) with $75 \%$ living in cities (EEA, 2007, 2010). While there are several regions (e.g., East Germany) where the human population is not growing, the expansion of built-up areas has continued in most regions, even where the population has declined (Haase et al., 2013). Several studies reported drivers of urban sprawl, including cultural, economic, demographic and social ones (e.g., Mann, 2009), i.e., population growth is not the only one. Increasing urban sprawl has many serious environmental, economic and social consequences. Important examples include the conversion of agricultural and other lands into built-up areas that are no longer available for food production, and have resulted in higher energy consumption, higher demand for mobility, higher landscape fragmentation, air pollution, higher spread of invasive species, degeneration or loss of most ecological soil functions, and reduced resilience of ecosystems (Ewing, 2008; Travisi et al., 2010; Wilson and Chakraborty, 2013). Urban sprawl is counteracting efforts to meet the stipulations of the Kyoto protocol to reduce greenhouse gas emissions (Bart, 2010; Hankey and Marshall, 2010; Jones and Kammen, 2014). Greater competition for land may result in the intensification of agricultural production, the lack of land for renewable energy production (Haber, 2007), and higher pressure on protected areas, which will, in turn, aggravate conflicts with conservation management due to light pollution, recreational activities, noise pollution, and other concerns (Güneralp and Seto, 2013; Mcdonald et al., 2009). Economic effects include higher costs for transportation infrastructure, traffic congestion, water provision and wastewater collection, electricity, waste management, and so on (Camagni et al., 2002; Carruthers and Ulfarsson, 2003). Social effects comprise longer commuting times, higher spatial segregation of social classes (Power, 2001; Le Goix, 2005), health effects due to the heat island effect and air pollution, and the altered perception of the landscape scenery and its character and identity due to the increasing penetration of the landscape by built-up areas. There are also some positive effects of urban sprawl, e.g., that it responds to the wish of people for affordable single houses with a garden and more privacy (Bruegmann, 2005).

From 2000 to 2006 , Europe lost $1,117.9 \mathrm{~km}^{2} / \mathrm{y}$ of natural and semi-natural areas (of which, on average, almost $50 \%$ was arable or cultivated land) to urban and other artificial land development (EEA, last accessed 31.12.2014). Between 2000 and 2030, there is a high probability (> 75\%) for about 77'500 $\mathrm{km}^{2}$ of the European continent to be converted 
to urban area (Seto et al., 2012). Future projections suggest an increase in urbanization of up to about $80 \%$ by 2050 (United Nations, 2014).

The expected continuation of urban sprawl in Europe and its associated threats demands action to control and manage the spread of built-up areas. Although primarily a national or regional responsibility, this is also more and more reflected at the European policy level (e.g., the 2011 Road Map for Resource-Efficient Europe as part of the Europe 2020 Strategy and the upcoming EC land communication "Land as resource"). Therefore, there is an urgent need to assess the extent of urban sprawl in and across Europe in a consistent and comparable way. In this paper, we determine for the first time the extent of urban sprawl for almost an entire continent.

\section{Materials \& Methods}

We used a recent method for measuring urban sprawl called Weighted Urban Proliferation (WUP), which combines three components (Jaeger and Schwick, 2014). While low-density development and the amount of built-up area are important parts of most definitions of urban sprawl in the literature (as reviewed by Jaeger et al., 2010b), the spatial distribution of the built-up areas is also an important dimension of urban sprawl. Accordingly, our definition of urban sprawl uses all three dimensions: "the more area built over in a given landscape (amount of built-up area) and the more dispersed the built-up area in the landscape (spatial configuration), and the higher the uptake of built-up area per inhabitant or job (lower utilization intensity in the built-up area), the higher the degree of urban sprawl" (Jaeger and Schwick, 2014). Various methods have been proposed to quantify sprawl patterns, ranging from single to multidimensional metrics (Galster et al., 2001; Hasse and Lathrop, 2003; Bhatta et al., 2010). One-dimensional metrics do not account for the multi-dimensionality of urban sprawl, while the combination of many sub-indicators raises the risk of including causes and consequences of sprawl rather than describing the phenomenon of sprawl itself (Jaeger et al., 2010b). The WUP metric combines the percentage of built-up area $(P B A)$, the spatial distribution of built-up areas (DIS), and the land-uptake per person (inhabitant or job) (LUP) in the built-up areas (Jaeger and Schwick, 2014). The LUP is measured in relation to the number of inhabitants and jobs because some built-up areas are more used for working and others more for living. The product of $P B A$ and $D I S$ is called urban permeation of the landscape (UP), which measures the degree to which a landscape is permeated by built-up area (Jaeger et al., 2010a). Thus, urban permeation is influenced by how much built-up area there is in a landscape and how it is arranged spatially.

For the calculation of WUP and its components, we used data on built-up areas taken from the European Copernicus land services - High Resolution Layer (HRL) Degree of Imperviousness data set of 2006 (the European Copernicus land services are carried out with funding by the European Union; EEA, 2013), and on inhabitants and jobs from Eurostat (EuroStat, last accessed 18.12.2014).

We determined urban sprawl at three scales: country (NUTS-0 according to the Nomenclature of Territorial Units of Statistics), NUTS-2 (basic regions for the application of regional policies), and the LEAC (Land and Ecosystem Accounting) grid level with a cell size of $1 \mathrm{~km}^{2}$ (Appendix A). For the grid level, we used weighted urban proliferation 
based on population data alone $\left(W U P_{p}\right)$, because job data are not available for all of Europe at this level.

\section{Results}

70 3.1. Sprawl at the country level

Large parts of Europe are affected by urban sprawl (Fig. 1). The value of WUP for all of Europe (32 countries considered) is $1.57 \mathrm{UPU} / \mathrm{m}^{2}$. The values of WUP for the countries vary considerably, ranging from very low values in Iceland and Scandinavian countries $\left(0.11 \mathrm{UPU} / \mathrm{m}^{2}\right)$ to very high values in Benelux countries $\left(6.48 \mathrm{UPU} / \mathrm{m}^{2}\right)$.

We present and discuss the results of sprawl for the countries that are members of the European Free Trade Association (EFTA), which includes all 28 countries of the European Union (EU), and Iceland, Liechtenstein, Norway and Switzerland (EU28+4). The maps in Fig. 2 also include 11 additional countries (Andorra, Albania, Bosnia, Kosovo, Macedonia, Monaco, Montenegro, San Marino, Serbia, Turkey and Vatican City - not part of EFTA), for which we have some results at the country and NUTS-2 level, but no information about population at the $1 \mathrm{~km}^{2}$ grid level. The dispersion of built-up areas is very heterogeneous among the countries, ranging from high values in Benelux countries and the UK to low values in southeastern Europe (Fig. 1, 2). The use of built-up areas per person also varies largely at the country level. For example, the more mountainous the land, the more humans need to concentrate the construction of their dwellings and industrial areas. The percentage of built-up area shows a similar pattern as WUP, and the differences are due to $D I S$ and $U D$.

Five factors are obviously involved in the development of the spatial pattern of sprawl in Europe: (1) climatic conditions (leading to lower population densities and lower levels of sprawl in Scandinavian countries); (2) a long history of industrialization (e.g., UK, BE, NL, parts of DE and FR); (3) socio-cultural building conditions, e.g., countries in southern Europe tend to have more compact built-up areas and lower LUP to increase shade; (4) topographic conditions (hills or mountains); (5) settlement history in former communist countries, which followed a different path of settlement development between 1945 and 1989.

90 The following example illustrates how the three components of WUP interact. Belgium (BE) and the Netherlands (NL) have different land property regimes and have followed different trajectories of urban development (33). Both are among the most densely populated countries in Europe, but the level of sprawl is higher in BE $\left(6.48 \mathrm{UPU} / \mathrm{m}^{2}\right)$ than in NL (6.41 UPU $/ \mathrm{m}^{2}$ ), even though the PBA is lower in BE (13.02\%) than in NL (14.53\%). This result is caused by the difference in dispersion $(D I S)$ which is higher in BE (47.02 UPU $\left./ \mathrm{m}^{2}\right)$ than in NL (46.48 UPU/ $/ \mathrm{m}^{2}$ ). The majority of land in NL was taken from the sea and is owned by the state. Thus, the use of the land was planned in a more systematic way, whereas BE is federalistic and every municipality has planned its land use for itself. The Netherlands has a polycentric urban structure in the Randstad region that exhibits some concentration of the population in urban centres, in clear contrast to Belgium which exhibits a disperse urbanization pattern due to the continuous increase in smaller urban centres in the countryside (Nijkamp and Esther, 2002). 

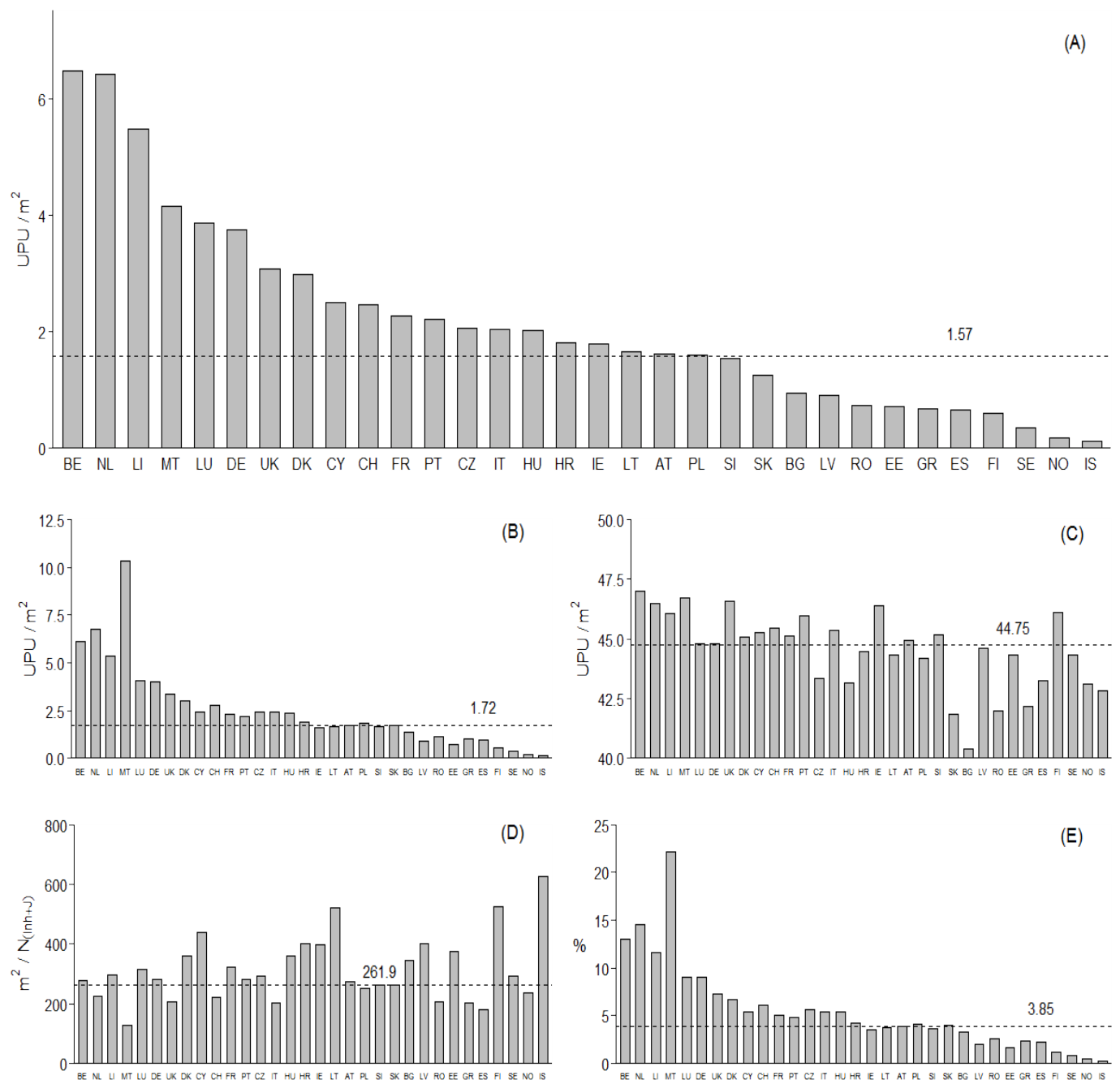

Figure 1: Bar diagram of country values for WUP (A), UP (B), DIS (C), LUP (D) and PBA (E) in 2006 with a line for Europe (EU28+4). The countries are ordered by decreasing value of $W U P$ (using the same order in all five diagrams). 


\subsection{Sprawl at the NUTS-2 level}

High sprawl values are found in the most strongly industrialized regions, in the vicinity of urban centers, and along major transportation corridors. Two major large clusters of high sprawl values ( $>4 \mathrm{UPU} / \mathrm{m}^{2}$, which we consider as highly sprawled on the NUTS-2 level) are located in north-eastern France, Belgium, the Netherlands and large parts of western Germany (including the Ruhr district) and in a large part of England. Sparsely inhabited and more rural regions exhibit low values $\left(<1 \mathrm{UPU} / \mathrm{m}^{2}\right)$. According to our concept of urban sprawl, it makes good intuitive sense to see high levels of sprawl in many NUTS-2 regions with a high population density. In contrast, in areas of very high population density, e.g., in Madrid, the level of sprawl is low (because LUP is low).

The spatial pattern of dispersion is more heterogeneous than the other sprawl components. Even Scandinavian countries show regions with high DIS values, similar to Benelux countries, while other regions have low values, particularly often in eastern Europe. All landlocked regions in Spain (except for Madrid) exhibit very low DIS values. Urban sprawl is a matter of degree. Our assessment of values $>4 \mathrm{UPU} / \mathrm{m}^{2}$ as 'high' is based on our qualitative understanding of sprawl and our knowledge and visual perception of landscapes in Europe. We also have studied a variety of settlement patterns in Switzerland and compared the qualitative assessment of their level of sprawl by experts, and found that the quantitative results agreed with the qualitative assessments of the various experts from science, spatial development, and regional planning (Jaeger and Schwick, 2014). Accordingly, we call NUTS-2 regions with $W U P>4 \mathrm{UPU} / \mathrm{m}^{2}$ as highly sprawled and NUTS-2 regions with $W U P>6 \mathrm{UPU} / \mathrm{m}^{2}$ as very highly sprawled. A refinement of this assessment would be possible in a future study.

Two points about the use of NUTS-2 regions are worth noting here:

(1) For the comparison of sprawl between NUTS-2 regions, it is useful to consider that only a certain proportion of the land is suitable for the construction of buildings. These proportions differ greatly among the regions due to geophysical conditions (e.g., glaciers and lakes) or due to protection regulations, e.g., forests in Switzerland (which have been protected from any kind of urban development since 1876; Federal Act on Forest 2013). These parts of the landscape can be excluded from the region investigated to make the values of WUP more directly comparable. We have calculated the differences in WUP with and without these areas that are not suitable for the construction of buildings. The adjusted values of WUP are higher, most of them (90\%) are within 10\% of their previous value, and only a few of them differ by more than $10 \%$ (Appendix B).

(2) Some NUTS-2 regions combine parts of a country that are quite different, for instance, lowlands and mountains (e.g., Austria, Switzerland), or dense population along the coast and low population in the hinterland (e.g., Spain). Therefore, other reporting units may be more suitable for the analysis of urban sprawl to detect these differences in sprawl in these different parts of the regions, and for comparisons between regions. The use of smaller reporting units is needed in such cases, such as the use of a $1-\mathrm{km}^{2}$ grid. 


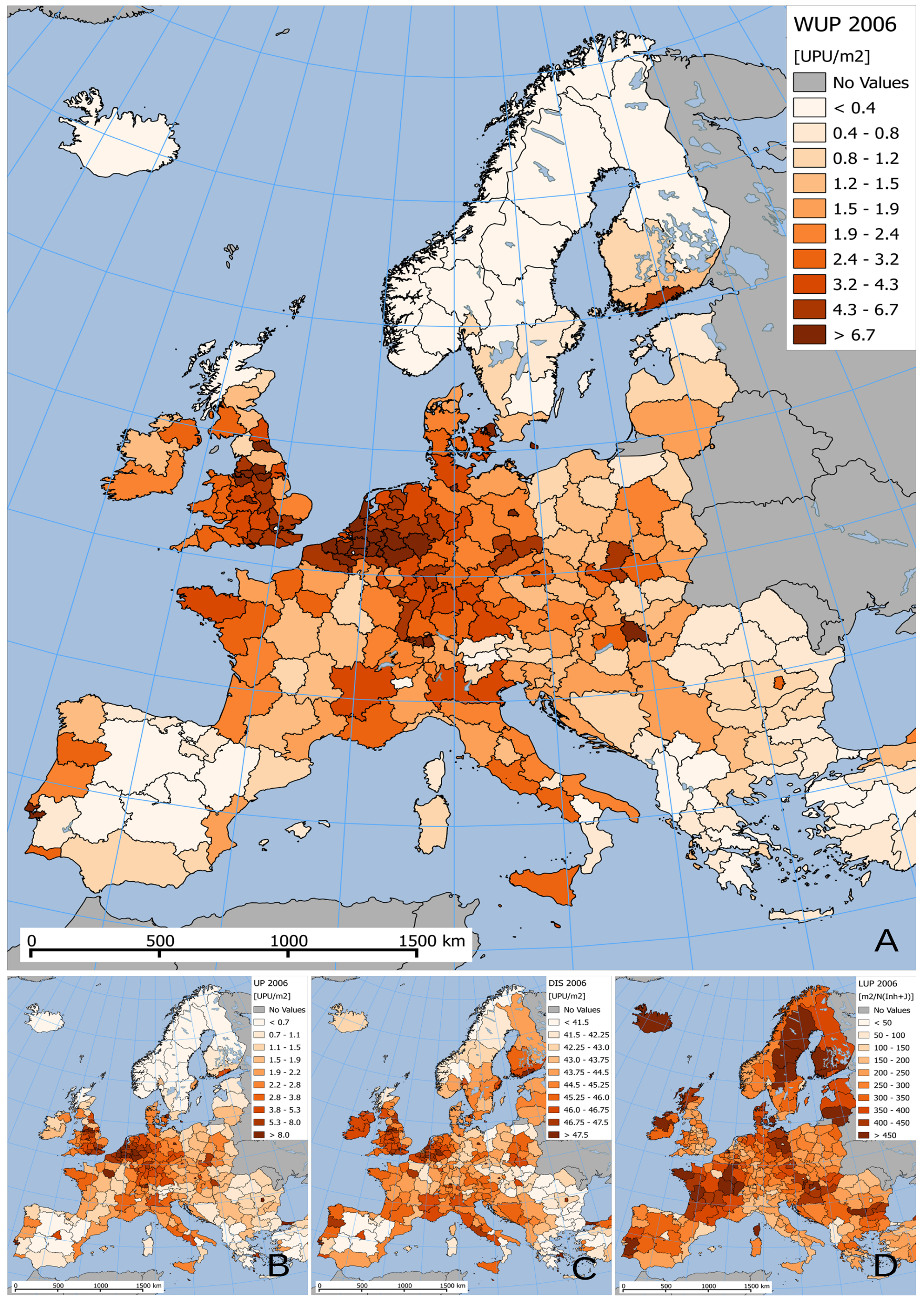

Figure 2: Map of $W U P(\mathrm{~A}), U P(\mathrm{~B}), D I S(\mathrm{C})$ and $L U P(\mathrm{D})$ in NUTS-2 regions 


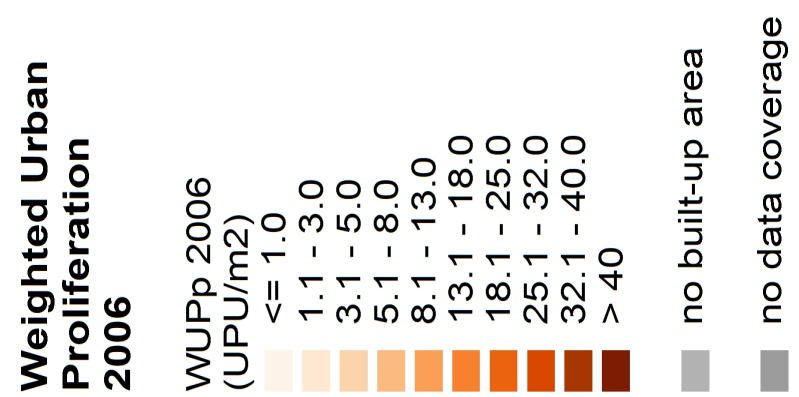

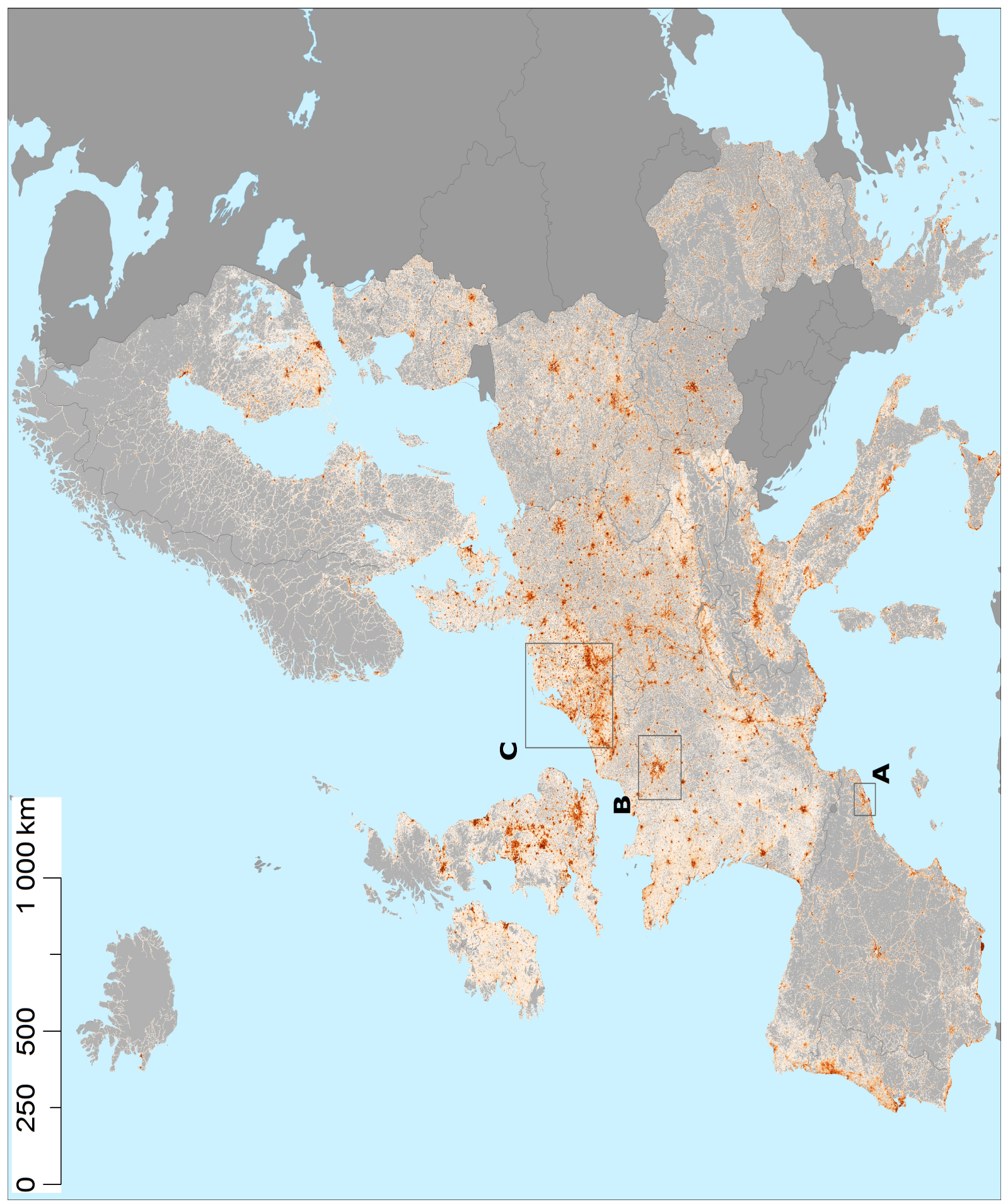




\subsection{Sprawl at the $1-\mathrm{km}^{2}$ grid level}

The maps of the $1-\mathrm{km}^{2}$ grid make patterns visible that are related to the network of cities and large transport corridors (Fig. 3). Sprawl is found around city centers, along large transportation corridors and along many coastlines. It is much lower in rural areas and in central areas because of their low land uptake per inhabitant, e.g., Paris (Fig. 4 (B)). Sprawl along the coast is observed in many places, for example, along the Côte d'Azur (French Riviera). Such places are often important centers for tourism. In northern Italy, sprawl is highly prevalent in the Po Plain, whereas in the Alps, sprawl is observed along the bottoms of valleys (Fig. 3). In London, built-up areas form an ellipse (diameter of about 30-50 km), and various towns with a high $P B A$ are found in the vicinity (Fig. 5 (D)). Dispersion exhibits intermediate values (47-50 UPU/ $\mathrm{m}^{2}$ ) and does not vary much in the area of high $P B A$, because it is filled up with built-up area. In contrast, there is large variability in the surroundings of London with intermediate values in town centers, surrounded by rings of high values at the edges of towns. Low values $\left(<30 \mathrm{UPU} / \mathrm{m}^{2}\right)$ are only found in the countryside. Land uptake per inhabitant is low in the city of London, and declines with increasing distance from the city center. These variables combined explain the values of WUP. A presentation of sprawl patterns at even higher resolution is possible in Switzerland at a 1-ha resolution (Appendix C).

\section{Discussion}

The advantages of the 1-km² scale are that it corresponds much better to the everyday perception of humans within their environment, and their ability to identify problematic areas of sprawl. It is thus useful for neighborhood planning and for the placement of new designated building zones. Temporal changes are also identified more easily at the 1$\mathrm{km}^{2}$ grid, because new buildings have a measurable effect at this scale.

However, a disadvantage of this scale is that the job data may not be available, as it is the case at the European level for the $1-\mathrm{km}^{2}$ grid $\left(W U P_{p}\right.$ is only based on inhabitants data). There are two options to solve this problem: (1) use job data available at a resolution between the NUTS-2 scale and the $1-\mathrm{km}^{2}$ grid, if such job data are available (e.g., for municipalities); (2) distribute jobs from the NUTS-2 regions into the grid cells based on remote sensing data (e.g., light emissions) and information from regional planning maps (e.g., zoning).

\subsection{Comparison with other studies and advantages of the WUP method}

Most studies about urban sprawl in Europe consider temporal changes in built-up areas for cities or urban regions (Kasanko et al., 2006; Turok and Mykhnenko, 2007; Catalán et al., 2008; Arribas-Bel et al., 2011; Oueslati et al., 2015) or select regions (EEA, 2006; Couch et al., 2007). The strongest increases in urban sprawl were reported for the outskirts of cities and for rural areas. Even many cities with declining population, most of which are found in Central and Eastern Europe (Turok and Mykhnenko, 2007), have exhibited an increase in urban sprawl (Reckien and Karecha, 2007; Siedentop and Fina, 2010; Salvati et al., 2013; Haase et al., 2014).

Our results are in agreement with studies published by the EEA (2006) and Siedentop and Fina (2012) as well as 

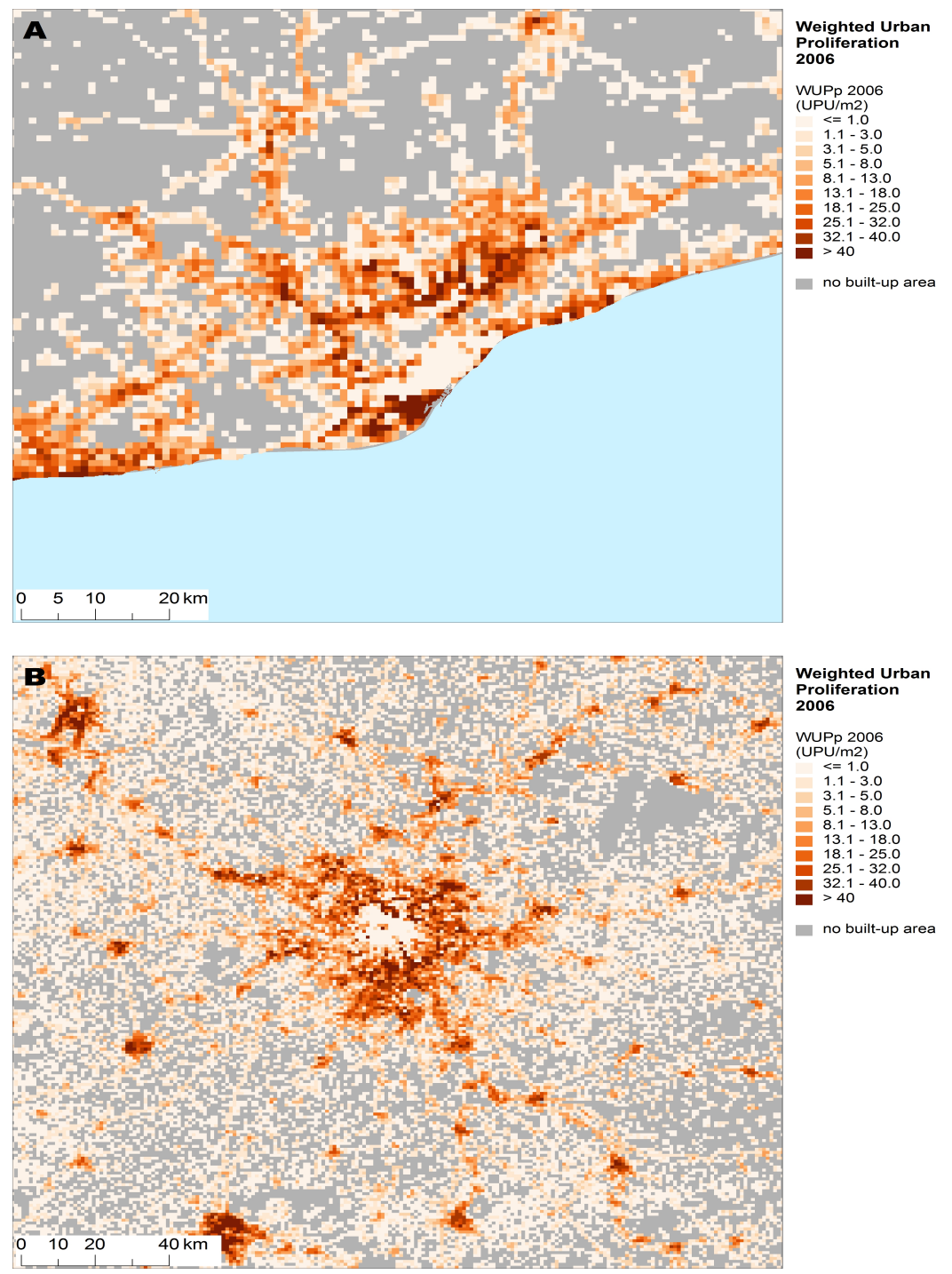

Weighted Urban Proliferation
2006 WUPp 2006 (UPU/m2) $1.1-3.0$
$\quad 3.1-5.0$
$5.1-8.0$
$8.1-13.0$ $8.1-13.0$
$13.1-18.0$
$18.1-25.0$
$25.1-32.0$
$32.1-40.0$ $32.1-40.0$
$>40$ no built-up area

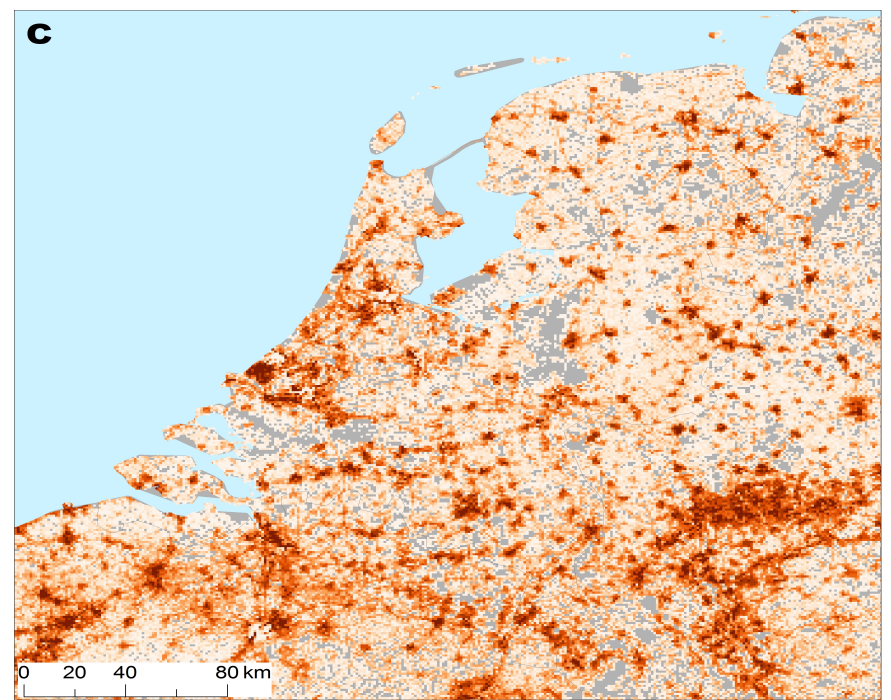




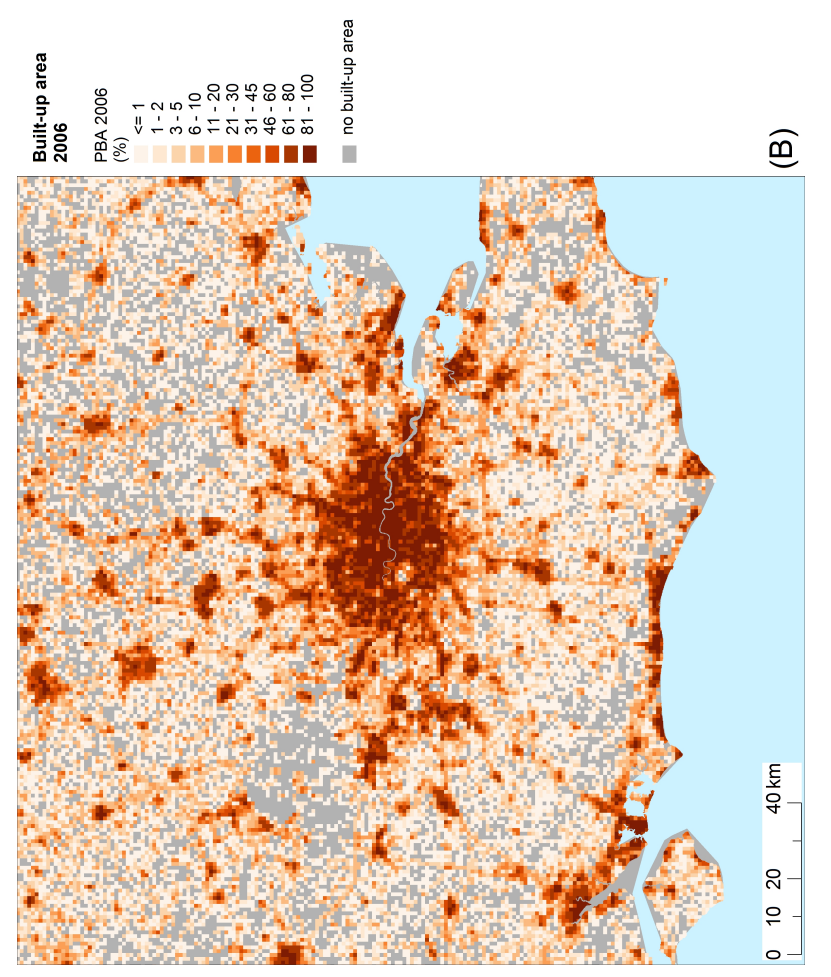

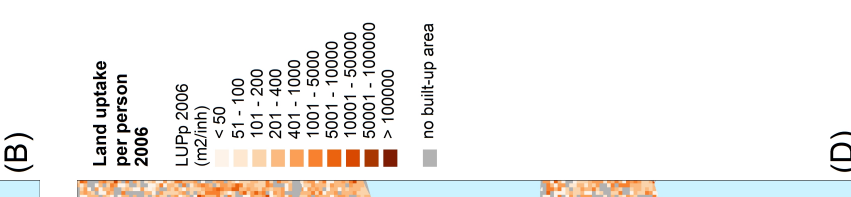

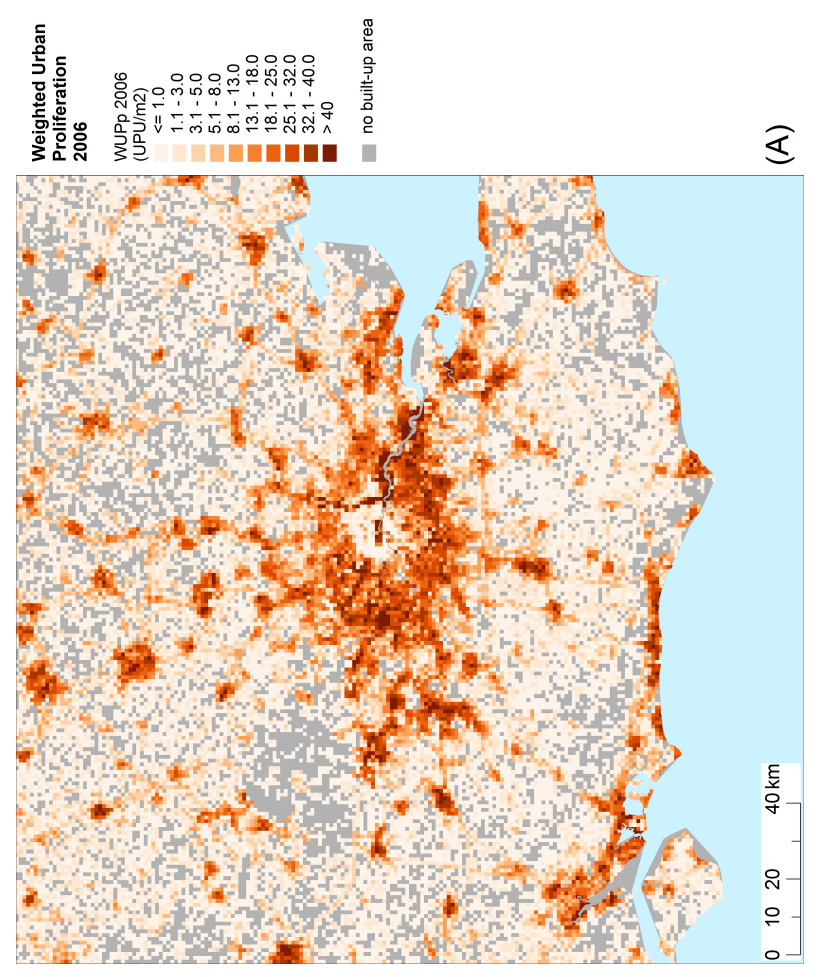

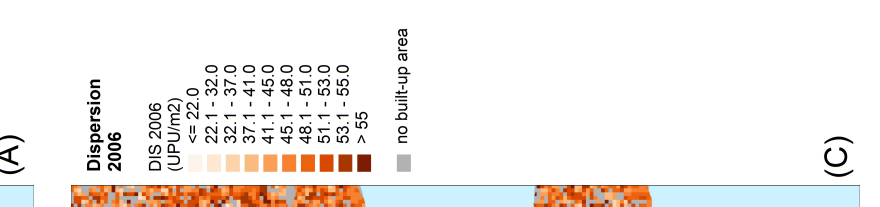

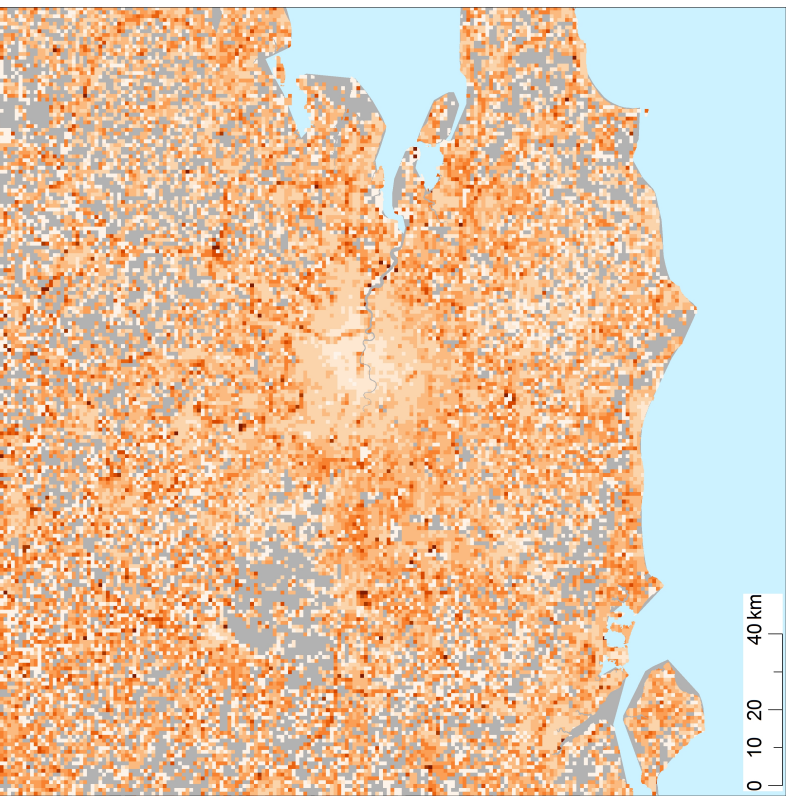

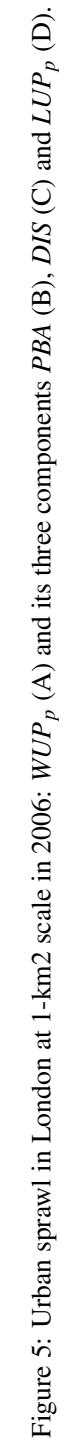

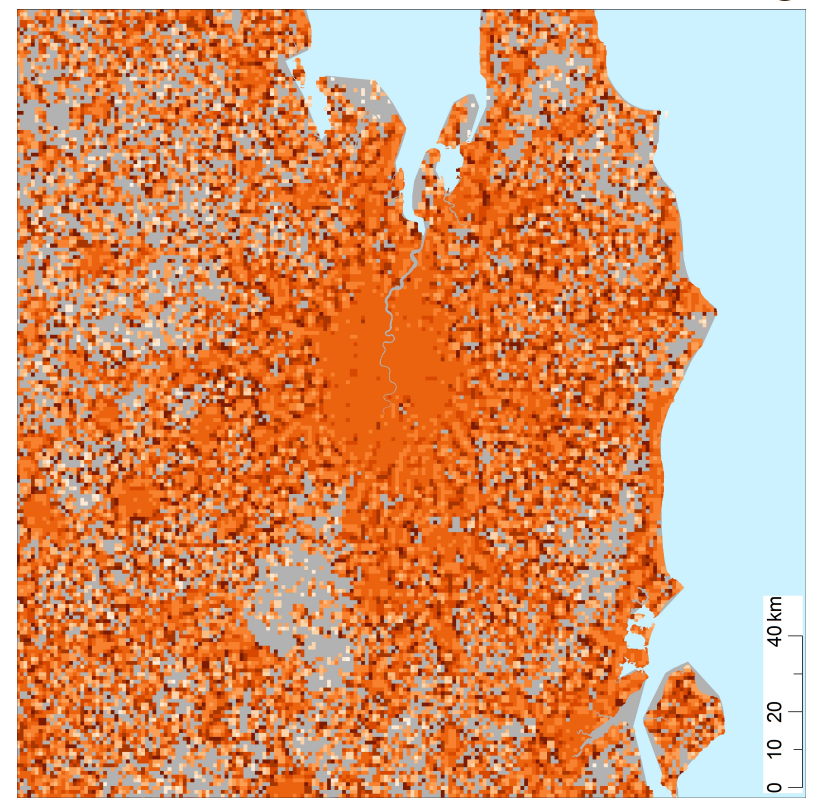


with the results from regional studies: low levels of sprawl in the Scandinavian countries and in the hinterlands of Spain, high sprawl in the Benelux countries, Western Germany, the central and southern regions of England, and along the coast of the Western Mediterranean sea. Depopulation of city cores and expansion of single housing areas have increased sprawl in many regions (Catalán et al., 2008; Siedentop and Fina, 2010). Couch et al. (2005, 2007) also identified liberal policies and gentrification as important drivers of urban sprawl in the UK. There are also some substantial differences in the results for some countries, due to the differences in the data layers for built-up areas. Siedentop and Fina (2012) used CORINE Land Cover (CLC) data for 1990, 2000 and 2006 with a resolution of 25 ha while the HRL layer has a resolution of 0.04 ha. In addition, different regions in each CLC layer are based on data from different years (up to 5 years difference), while the HRL layer includes data of only one year. These differences are most pronounced in regions that have a dispersed settlement structure. For example, in sparsely settled regions small patches of built-up area are not captured by the CLC data (e.g., Finland), while in densely settled regions built-up areas often have many small open spaces which are also too small to be captured by the CLC data (e.g., in Belgium). In contrast, regions with a more compact settlement structure the differences between the two data sets are smaller (e.g., in the Netherlands).

This paper demonstrates how urban sprawl can be measured on a continental and even on a global scale. While sufficiently accurate data on built-up areas are available from all parts of the world (Esch et al., 2012), comparability among countries may be limited. In many countries, this is also feasible for earlier points in time (e.g., Jaeger and Schwick (2014) for Switzerland). Data about inhabitants and jobs may be more difficult to obtain. They are often only available for larger spatial units and then need to be broken down into smaller units (see above). However, there are initiatives towards global gridded population data (e.g., WorldPop, Landscan, GRUMP, UNEP, GPD, GPW). Even when data regarding the number of jobs are unavailable, the WUP method can still be applied because the biggest contribution to sprawl comes from residential areas, where there are almost no jobs (for example in Switzerland, $51.2 \%$ residential sprawl, $15.4 \%$ commercial/industrial sprawl, $32.8 \%$ mixed zones sprawl, $0.7 \%$ recreational/tourism sprawl). Therefore, larger regions are comparable even without job data because the ratio between inhabitants and jobs exhibits less variability in larger regions, and issues due to the lack of job data become relevant only at a higher resolution (e.g., for the $1-\mathrm{km}^{2}$ grid, in downtown areas).

The WUP method captures all types of settlement well through the combination of its three components, i.e., it measures a rather complex phenomenon in a relatively simple way. The presentation of the three components as separate indicators is also useful towards understanding and interpreting the values of WUP. The combination of three sprawl components into one metric is an important advantage, compared to previous studies where only single components of sprawl (e.g., built-up area) are reported, dispersion is either neglected or difficulties are encountered in quantifying dispersion (Razin and Rosentraub, 2000; Yeh and Li, 2001), some causes or consequences of sprawl are included (Torrens, 2008), or too many aspects of sprawl are integrated into a single, less transparent index (Frenkel and Ashkenazi, 2008). In addition, previous studies have often focused on large cities and their surroundings and have neglected less densely populated areas (rural sprawl) (e.g., EEA, 2006) or considered only one scale of analysis 
(Couch and Karecha, 2006; Chorianopoulos et al., 2010; Angel et al., 2011).

The WUP method meets the 34 requirements for environmental indicator selection in environmental reporting well that were reviewed by Niemeijer and de Groot (2008). Qualitative aspects are also important and need to be considered in regional planning (using qualitative methods). While the WUP is not intended to replace such qualitative methods, it can complement them to improve the tool-box of regional planners.

\subsection{Options for the application of the WUP method and wider implications}

The quantification of sprawl and its three components is highly useful in many ways. Its use in environmental monitoring systems can bring more objectivity into discussions of the issue of sprawl and its development over time, for instance, if economic growth has been decoupled from sprawl. Monitoring efforts require comparable data about built-up areas from different points in time. When sensor technology changes to increase spatial resolution, a conversion factor may be useful (based on data for the same year from both datasets). It may also be possible to generalize the more detailed data to the resolution of the previous data quality to compare the values. This is a general issue in the observation of temporal changes of built-up areas.

Most importantly, this method makes it possible for planners to predict future levels of sprawl for various planning scenarios, to introduce environmental quality standards (objectives and limits), and to evaluate the effectiveness of measures to control sprawl. Thus, the WUP method provides valuable assistance in the designation of new settlement areas and in the limitation and densification of existing built-up areas. For example, the extent, spatial location, and density of new buildings zones can be analyzed and modified to minimize their contribution to sprawl (comparison of planning scenarios). Similarly, the WUP method allows to estimate the contribution of planned building zones to urban sprawl and to decide upon counteractive measures. For example, existing building zones (that are not yet built over) should be de-zoned when they substantially contribute to urban sprawl. In addition, in regions with a dwindling population, the deconstruction of buildings or built-up areas on agriculturally or ecologically valuable land can reduce sprawl and increase ecosystem services. Such designations should take into account the cumulative effect of all planned future developments. Planners can also use WUP to assess the potential to which densification can reduce the level of urban sprawl, i.e., where the potential is significant.

The need for such methods is high, since sprawl is a major threat to sustainable land use in Europe and because it is increasing rapidly (Siedentop and Fina, 2012). The need for action is a matter of degree and will depend on the particular landscape (since some landscapes may be more sensititive than others). How damaging the various effects of sprawl are and how urgently action is needed to address them is an important topic for future research. Therefore, we propose:

(1) a European de-sprawling strategy which can consist of the following strategic measures for the containment of sprawl:

- Monitoring urban sprawl to document landscape change, to compare regions and identify sprawl hotspots, to estimate the rates of change (in particular if historical data are available), and to detect changes in trends; 
- Establishing quantitative targets, limits, and benchmarks to control urban sprawl and the implementation of performance control; identified by Haber (2007) as the three central "ecological traps" that threaten humanity. Our results for Europe provide data for monitoring and assessing these increasing threats, while the WUP method can assist in addressing them. This study is the first that measures the degree of urban sprawl across Europe consistently at three scales and 

other studies, and it provides a basis for monitoring temporal changes.

\section{Acknowledgements}

We thank the Swiss Federal Office for the Environment (FOEN) and the European Environmental Agency (EEA) for the financial support, and the European Earth Observation Programme Copernicus, funded by the EU, for providing data about land cover types. We also thank two anonymous reviewers for their constructive comments.

\section{References}

Angel, S., Parent, J., Civco, D.L., Blei, A., Potere, D., 2011. The dimensions of global urban expansion: Estimates and projections for all countries, 2000-2050. Progress in Planning 75, 53 - 107. doi:10.1016/j ·progress. 2011.04 .001$.

Arribas-Bel, D., Nijkamp, P., Scholten, H., 2011. Multidimensional urban spawl in Europe: A self-organizing map approach. Computers, Environment and Urban Systems 35, 263 - 275. doi:10.1016/j . compenvurbsys. 2010.10.002.

Bart, I.L., 2010. Urban sprawl and climate change: A statistical exploration of cause and effect, with policy options for the EU. Land Use Policy 27, 283 - 292. doi:10.1016/j.landusepol.2009.03.003.

Bhatta, B., Saraswati, S., Bandyopadhyay, D., 2010. Urban sprawl measurement from remote sensing data. Applied Geography 30,731 - 740. doi:10.1016/j.apgeog.2010.02.002.

Camagni, R., Cristina, M.G., Rigamonti, P., 2002. Urban mobility and urban form: the social and environmental costs of different patterns of urban expansion. Ecological Economics 40, 199 - 216. doi:10.1016/S0921-8009(01)00254-3.

Carruthers, J.I., Ulfarsson, G.F., 2003. Urban sprawl and the cost of public services. Environment and Planning B: Planning and Design $30,503-$ 522. doi:10.1068/b12847.

Catalán, B., Saurí, D., Serra, P., 2008. Urban sprawl in the Mediterranean?: Patterns of growth and change in the Barcelona Metropolitan Region 1993-2000. Landscape and Urban Planning 85, 174 - 184. doi:10.1016/j . landurbplan.2007.11.004.

Chen, J., 2007. Rapid urbanization in China: A real challenge to soil protection and food security. CATENA 69, 1 - 15. doi:10.1016/j . catena. 2006.04 .019$.

Chorianopoulos, I., Pagonis, T., Koukoulas, S., Drymoniti, S., 2010. Planning, competitiveness and sprawl in the Mediterranean city: The case of Athens. Cities 27, 249 - 259. doi:10.1016/j.cities.2009.12.011.

Conseil fédéral Suisse, 2012. Stratégie pour le développement durable 2012-2015. Berne, Switzerland.

Couch, C., Karecha, J., 2006. Controlling urban sprawl: Some experiences from Liverpool. Cities 23, 353 - 363. doi:10.1016/j . cities .2006. 05.003.

Couch, C., Karecha, J., Nuissl, H., Rink, D., 2005. Decline and sprawl: an evolving type of urban development - observed in Liverpool and Leipzig. European Planning Studies 13, 117 - 136. doi:10.1080/0965431042000312433.

Couch, C., Leontidou, L., Petschel-Held, G. (Eds.), 2007. Urban Sprawl in Europe. Landscapes, Land Use Change \& Policy. Blackwell Publishing. 
EEA, 2006. Urban Sprawl in Europe. The ignored challenge. Report No. 10, European Environmental Agency (EEA). URL: http://www.eea. europa.eu/publiations/eea_report_2006_10/eea_report_10_2006.pdf.

EEA, 2007. The pan-European environment: glimpses into an uncertain future. Report No. 4, European Environmental Agency, Copenhagen.

URL: http://www.eea.europa.eu/publications/eea_report_2007_4/at_download/file.

EEA, 2010. The European environment - state and outlook 2012: synthesis. European Environmental Agency, Copenhagen.

EEA, 2013. GIO land (GMES/Copernicus initial operations land) High Resolution Layers (HRLs) summary of product specifications. GIO land team at the EEA.

EEA, last accessed 31.12.2014. Land take (CSI 014/LSI 001). http://www.eea.europa.eu/data-and-maps/indicators/land-take-2/assessment.

Eigenbrod, F., Bell, V.A., Davies, H.N., Heinemeyer, A., Armsworth, P.R., Gaston, K.J., 2011. The impact of projected increases in urbanization on ecosystem services. Proceedings of the Royal Society of London B: Biological Sciences 278, 3201 - 3208. doi:10.1098/rspb.2010.2754.

Esch, T., Taubenböck, H., Roth, A., Heldens, W., Felbier, A., Thiel, M., Schmidt, M., Müller, A., Dech, S., 2012. TanDEM-X mission - new perspectives for the inventory and monitoring of global settlement patterns. Journal of Applied Remote Sensing 6, 061702-1-061702-21. doi:10.1117/1.JRS.6.061702.

European Commission, 2011. Regions in the European Union. Nomenclature of territorial units for statistics NUTS 2010/EU-27. EuroStat, Methodologies \& Working papers, Cat. No KS-RA-11-011-EN-N, Luxembourg. doi:10.2785/15544.

EuroStat, last accessed 18.12.2014. http://ec.europa.eu/eurostat/web/main/home.

Ewing, R.H., 2008. Characteristics, Causes, and Effects of Sprawl: A Literature Review, in: Marzluff, J.M., Shulenberger, E., Endlicher, W., Alberti, M., Bradley, G., Ryan, C., Simon, U., ZumBrunnen, C. (Eds.), Urban Ecology. Springer US, pp. 519-535. doi:10.1007/ 978-0-387-73412-5_34.

Food and Agriculture Organization of the United Nations (FAO), 2011. The state of the world's land and water rresource for food and agriculture. - Managing sustems at risk. Roem and Earthscan.

Frenkel, A., Ashkenazi, M., 2008. Measuring urban sprawl: how can we deal with it? Environment and Planning B: Planning and Design 35, 56 79. doi:10. 1068/b32155.

Galster, G., Hanson, R., Ratcliffe, M.R., Wolman, H., Coleman, S., Freihage, J., 2001. Wrestling sprawl to the ground: Defining and measuring an elusive concept. Housing Policy Debate 12,681 - 717. doi:10.1080/10511482.2001.9521426.

Gerland, P., Raftery, A.E., Ševíková, H., Li, N., Gu, D., Spoorenberg, T., Alkema, L., Fosdick, B.K., Chunn, J., Lalic, N., Bay, G., Buettner, T., Heilig, G.K., Wilmoth, J., 2014. World population stabilization unlikely this century. Science 346, 234 - 237. doi:10.1126/science. 1257469

Güneralp, B., Seto, K.C., 2013. Futures of global urban expansion: uncertainties and implications for biodiversity conservation. Environmental Research Letters 8, 014025. doi:10.1088/1748-9326/8/1/014025.

Haase, A., Rink, D., Grossmann, K., Bernt, M., Mykhnenko, V., 2014. Conceptualizing urban shrinkage. Environment and Planning A 46, 1519 1534. doi:10.1068/a46269.

Haase, D., Kabisch, N., Haase, A., 2013. Endless Urban Growth? On the Mismatch of Population, Household and Urban Land Area Growth and Its Effects on the Urban Debate. PLOS One 8, e66531. doi:10.1371/journal pone.0066531.

Haber, W., 2007. Energy, food, and land - The ecological traps of humankind. Environmental Science and Pollution Research - International 14, 359 - 365. doi:10.1065/espr2007.09.449.

Hankey, S., Marshall, J.D., 2010. Impacts of urban form on future US passenger-vehicle greenhouse gas emissions. Energy Policy 38 , 4880 4887. doi:10.1016/j.enpol.2009.07.005. special Section on Carbon Emissions and Carbon Management in Cities with Regular Papers.

Hasse, J.E., Lathrop, R.G., 2003. Land resource impact indicators of urban sprawl. Applied Geography 23, 159 - 175. doi:10.1016/j . apgeog . 2003.08 .002 .

Jaeger, J.A., Schwick, C., 2014. Improving the measurement of urban sprawl: Weighted Urban Proliferation (WUP) and its application to Switzerland. Ecological Indicators 38, 294 - 308. doi:10.1016/j .ecolind.2013.11.022.

Jaeger, J.A.G., Bertiller, R., Schwick, C., Cavens, D., 2010a. Urban permeation of landscapes and sprawl per capita: New measures of urban 
sprawl. Ecological Indicators 10, 427 - 441. doi:10.1016/j.ecolind.2009.07.010.

Jaeger, J.A.G., Bertiller, R., Schwick, C., Kienast, F., 2010b. Suitability criteria for measures of urban sprawl. Ecological Indicators 10,397 - 406. doi:10.1016/j.ecolind.2009.07.007.

Jones, C., Kammen, D.M., 2014. Spatial Distribution of U.S. Household Carbon Footprints Reveals Suburbanization Undermines Greenhouse Gas Benefits of Urban Population Density. Environmental Science \& Technology 48, 895 - 902. doi:10.1021/es4034364.

Kasanko, M., Barredo, J.I., Lavalle, C., McCormick, N., Demicheli, L., Sagris, V., Brezger, A., 2006. Are European cities becoming dispersed?: A comparative analysis of 15 European urban areas. Landscape and Urban Planning 77, 111 - 130. doi:10.1016/j.landurbplan.2005.02. 003.

Lambin, E.F., Turner, B., Geist, H.J., Agbola, S.B., Angelsen, A., Bruce, J.W., Coomes, O.T., Dirzo, R., Fischer, G., Folke, C., George, P., Homewood, K., Imbernon, J., Leemans, R., Li, X., Moran, E.F., Mortimore, M., Ramakrishnan, P., Richards, J.F., Skånes, H., Steffen, W., Stone, G.D., Svedin, U., Veldkamp, T.A., Vogel, C., Xu, J., 2001. The causes of land-use and land-cover change: moving beyond the myths. Global Environmental Change 11, 261 - 269. doi:10.1016/S0959-3780(01)00007-3.

Le Goix, R., 2005. Gated Communities: Sprawl and Social Segregation in Southern California. Housing Studies 20, 323 - 343. doi:10.1080/ 026730303042000331808.

Mann, S., 2009. Institutional cuasesof urban and rural sprawl in Switzerland. Land Use Policy 26, 919 - 924. doi:10.1016/j.landusepol. 2008.11 .004 .

Mcdonald, R.I., Forman, R.T., Kareiva, P., Neugarten, R., Salzer, D., Fisher, J., 2009. Urban effects, distance, and protected areas in an urbanizing world. Landscape and Urban Planning 93, 63 - 75. doi:10.1016/j . landurbplan.2009.06.002.

Montgomery, M.R., 2008. The Urban Transformation of the Developing World. Science 319, 761 - 764. doi:10.1126/science.1153012.

Niemeijer, D., de Groot, R.S., 2008. A conceptual framework for selecting environmental indicator sets. Ecological Indicators 8 , $14-25$. doi:10.1016/j.ecolind.2006.11.012.

Nijkamp, G., Esther, P. (Eds.), 2002. Urban development in the Netherlands: New Perspectives. number 2002-1A in Research Memoranda, Faculteit der Economische Wetenschappen en Econometrie, Universiteit Amsterdam. URL: http://dare.ubvu.vu.nl/handle/1871/1655.

Orlitová, E., Soukup, T., Kopecky, M., Vobora, V., Gregor, M., Schwick, C., Jaeger, J., 2012. Urban sprawl typology: Critical analysis of input datasets, indicators calculated and dataflows proposal. Working document. European Environment Agency.

Oueslati, W., Alvanides, S., Garrod, G., 2015. Determinants of urban sprawl in European cities. Urban Studies 52, 1594 - 1614. doi:10.1177/ 0042098015577773.

Power, A., 2001. Social Exclusion and Urban Sprawl: Is the Rescue of Cities Possible? Regional Studies 35,731 - 742. doi:10.1080/ 00343400120084713.

Razin, E., Rosentraub, M., 2000. Are Fragmentation and Sprawl Interlinked?: North American Evidence. Urban Affairs Review 35,821 - 836. doi:10.1177/10780870022184697.

Reckien, D., Karecha, J., 2007. Sprawl in European Cities: The Comparative Background, in: Couch, C., Leontidou, L., Petschel-Held, G. (Eds.), Urban Sprawl in Europe. Landscapes, Land Use Change \& Policy. Blackwell Publishing. chapter 2, pp. 39 - 68.

Salvati, L., Morelli, V.G., Rontos, K., Sabbi, A., 2013. Latent Exurban Development: City Expansion Along the Rural-To-Urban Gradient in Growing and Declining Regions of Southern Europe. Urban Geography 34, 376 - 394. doi:10.1080/02723638.2013.778675.

Schwick, C., Kienast, F., Jaeger, J.A., (under revision). The accelerated increase of urban sprawl in Switzerland: Time series from 1885 to 2010 , potential drivers and scenarios for 2050. Landscape and Urban Planning .

Seto, K.C., Güneralp, B., Hutyra, L.R., 2012. Global forecasts of urban expansion to 2030 and direct impacts on biodiversity and carbon pools. Proceedings of the National Academy of Sciences 109, 16083 - 16088. doi:10.1073/pnas. 1211658109.

Siedentop, S., Fina, S., 2010. Urban Sprawl beyond Growth: the Effect of Demographic Change on Infrastructure Costs. Flux 1, 90 - 100. URL: www.cairn.info/revue-flux-2010-1-page-90.htm.

Siedentop, S., Fina, S., 2012. Who sprawls most? Exploring the patterns of urban growth across 26 European countries. Environment and Planning A 44, 2765 - 2784. doi:10.1068/a4580. 
Song, Y., Zenou, Y., 2006. Property tax and urban sprawl: Theory and implications for US cities . Journal of Urban Economics 60,519 - 534. doi:http://dx.doi.org/10.1016/j.jue.2006.05.001.

Swisstopo, 2002. Vector25. http://www.swisstopo.admin.ch/internet/swisstopo/en/home/products/landscape/vector25.html, last accessed 25.08.2014

Torrens, P.M., 2008. A Toolkit for Measuring Sprawl. Applied Spatial Analysis and Policy 1, 5-36. doi:10.1007/s12061-008-9000-x.

Travisi, C.M., Camagni, R., Nijkamp, P., 2010. Impacts of urban sprawl and commuting: a modelling study for Italy. Journal of Transport Geography 18,382 - 392. doi:10.1016/j.jtrangeo.2009.08.008.

Turok, I., Mykhnenko, V., 2007. The trajectories of European cities, 1960 - 2005. Cities 24, 165 - 182. doi:10.1016/j .cities.2007.01.007. United Nations, 2014. World Urbanization Prospects: The 2014 Revision. URL: http://esa.un.org/unpd/wup/index.htm.

Wilson, B., Chakraborty, A., 2013. The Environmental Impacts of Sprawl: Emergent Themes from the Past Decade of Planning Research. Sustainability 5, $3302-3327$. doi:10.3390/su5083302.

Yeh, A., Li, X., 2001. Measurement and monitoring of urban sprawl in a rapidly growing region using entropy. Photogrammetric Engineering And Remote Sensing 67, 83 - 90. URL: http://hub.hku.hk/handle/10722/176280. 


\section{Appendix A. Materials and Methods}

\section{Appendix A.1. Reporting Units}

We analyzed urban sprawl in Europe at the national and regional scale, and also using a $1-\mathrm{km}^{2}$ raster grid. The national scale comprises the 2006 European country borders. For the regional scale, we used NUTS-2 regions, which are territorial units defined by the European Commission (European Commission, 2011). These territorial units are derived from smaller national administrative units, which are merged according to their population size to form a NUTS-2 region. A NUTS-2 region contains 800,000 - 3,000,000 inhabitants, however, there are some exceptions (e.g., Åland (Sweden) - 26,923, Île de France (France) - 11,598,866).

The calculation of weighted urban proliferation at the national and regional scales included jobs and inhabitants, while for the raster grid only inhabitants were used.

\section{Appendix A.2. Weighted urban proliferation (WUP) and its three components}

The WUP metric combines three components: dispersion, utilization density, and urban permeation (Jaeger and Schwick, 2014). Dispersion (DIS) reflects the distribution of buildings in the landscape from a geometric perspective using Euclidean distance and is expressed in urban permeation units per $\mathrm{m}^{2}\left(\mathrm{UPU} / \mathrm{m}^{2}\right)$ of the built-up area. Land uptake per person $(L U P)$ describes the use of built-up area per person working or living in an area $\left(\mathrm{m}^{2}\right.$ per inhabitant or job). Built-up areas with many inhabitants and employees are considered less sprawled. Urban permeation (UP) represents the product of the proportion of built-up area $(P B A)$ in a landscape multiplied by the level of dispersion of the built-up area in the landscape (in $\mathrm{UPU} / \mathrm{m}^{2}$ ).

$$
W U P=U P \cdot w_{1}(D I S) \cdot w_{2}(L U P)
$$
or job) $=0.8$ 


\section{Appendix A.3. Data}

Built-up area is defined as every surface covered by man-made structures, excluding roads and railways. Based on this definition, we used the Pan-European High Resolution Layer (HRL) for Europe from the Copernicus Land Monitoring Service to assess the extent of surAuthorface sealed with artificial buildings (EEA, 2013). The HRL is a $100 \mathrm{~m} \times 100 \mathrm{~m}$ grid cell layer, which is produced from satellite imagery with a $20 \mathrm{~m} \cdot 20 \mathrm{~m}$ pixel resolution and thus provides more detailed information $(20 \mathrm{~m} \cdot 20 \mathrm{~m}=0.04 \mathrm{ha}$ ) about sealed surfaces than Corine Land Cover (CLC) (5 ha) or the Urban Atlas (0.25 ha).

Moreover, previous comparisons of the CLC and High Resolution Soil Sealing Layer with the Vector25 layer from Switzerland (Swisstopo, 2002), which reproduces artificial and natural structures at a resolution of $3-8 \mathrm{~m}$ for Switzerland, have shown that the CLC overestimated urban area (Orlitová et al., 2012). While the HRL provided similar results to those of the Vector25 layer, motorways and other larger roads are included. Consequently the difference between the results from the Vector25 and HRL for Switzerland was used to correct the values from the HRL using the following two conditions: (1) no correction when the sealed area is $100 \%$, and for Switzerland (2) the extent of sealed area in the Swiss Vector25 (4.25\%) is corrected using the factor 1.408686 to calculate the corresponding correct built-up area in the HRL. A simple regression approach was used, with $x$ as the portion of sealed area and $y$ as the correction values.

In order to better reflect the true situation of land uptake per person $(L U P)$, commuting-corrected employee numbers were used and full-time equivalents considered. Workers can be employed in the same region they live in, but they can also travel to work from another region of the same country or from abroad. We accounted for the movement of people to their work places by using commuting-corrected employee numbers.

Information about full- and part-time jobs was included by using full-time equivalents to present a more reliable picture of $L U P$ and urban sprawl. The correction factor for full-time equivalents was derived from data on full-time equivalents for Switzerland in 2002. In this year, Switzerland had 3,945,000 employees, 2,748,000 full-time (> 90\%) and 1,217,000 part-time ( $<90 \%$ ) employees. 613,000 part-time employees worked 50 - 89\%, while 604,000 worked less than $50 \%$, which results in a correction factor of 0.849 . This correction factor was used to calculate an overall correction factor.

\section{Appendix B. Delineation of reporting units and calculation of adjusted WUP values}

Urban sprawl can be measured with and without the inclusion of those areas that are not suitable for the construction of buildings (called "irreclaimable areas"). Although we took the entire area of our reporting units into account, this appendix also provides information about the changes in the WUP values when excluding the irreclaimable areas. The types of areas considered as not feasible for the construction of buildings in Europe were taken from CORINE Land Cover (CLC) and included:

- glaciers and perpetual snow, 
- water bodies,

- coastal lagoons,

- estuaries,

- sea and ocean,

- inland marshes,

- peat bogs,

- salt marshes,

- salines,

- and intertidal flats.

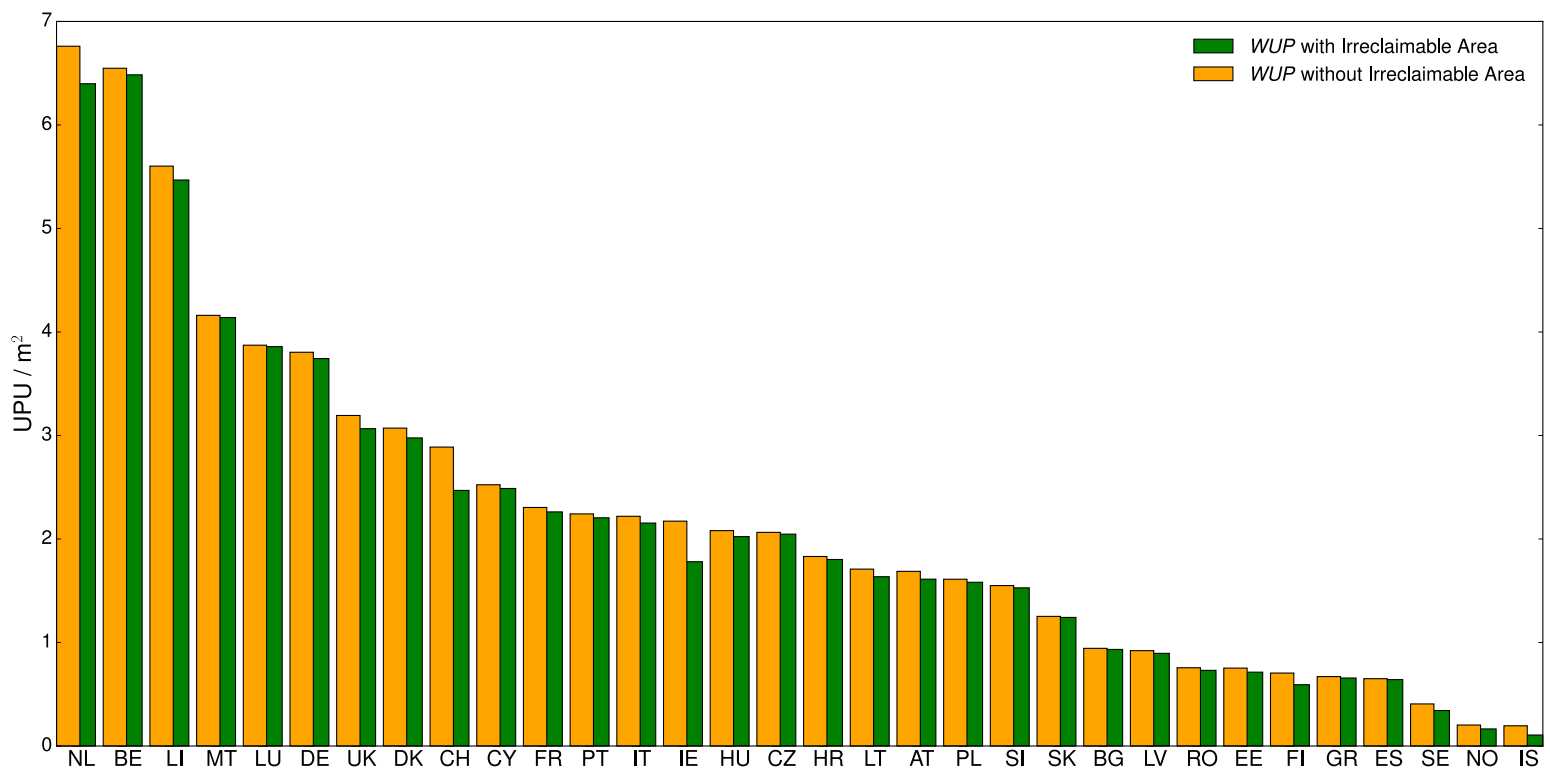

Figure B.1: WUP values for EU28+4 with and without consideration of the irreclaimable areas for the year 2006.

Excluding the areas not suitable for construction from the reporting units used in the calculation of urban sprawl results in larger WUP values for all countries (Fig. B.1). Largest absolute differences between WUP values with and without accounting for irreclaimable areas would be expected in countries with larger spatial extent of the excluded land-cover types. For example, the Netherlands are known for their long struggle with the sea to regain land due to their low elevation above (or even below) sea level. Many Dutch areas are characterized by the influence of the 
sea with salt marshes, previously intertidal flats transformed to constructional ground and protected now by dikes, peat bogs and water courses. In contrast, Ireland has coastal lines characterized to a certain extent by cliff lines and small, but rocky hills at the edges of the island, while roughly $15 \%$ of the area of Switzerland are covered by the Alps. However, additional areas can be considered as not suitable for buildings (e.g., rocks, at least in some regions; protected areas, such as forests in Switzerland), but there are no consistent datasets available across Europe for such areas.

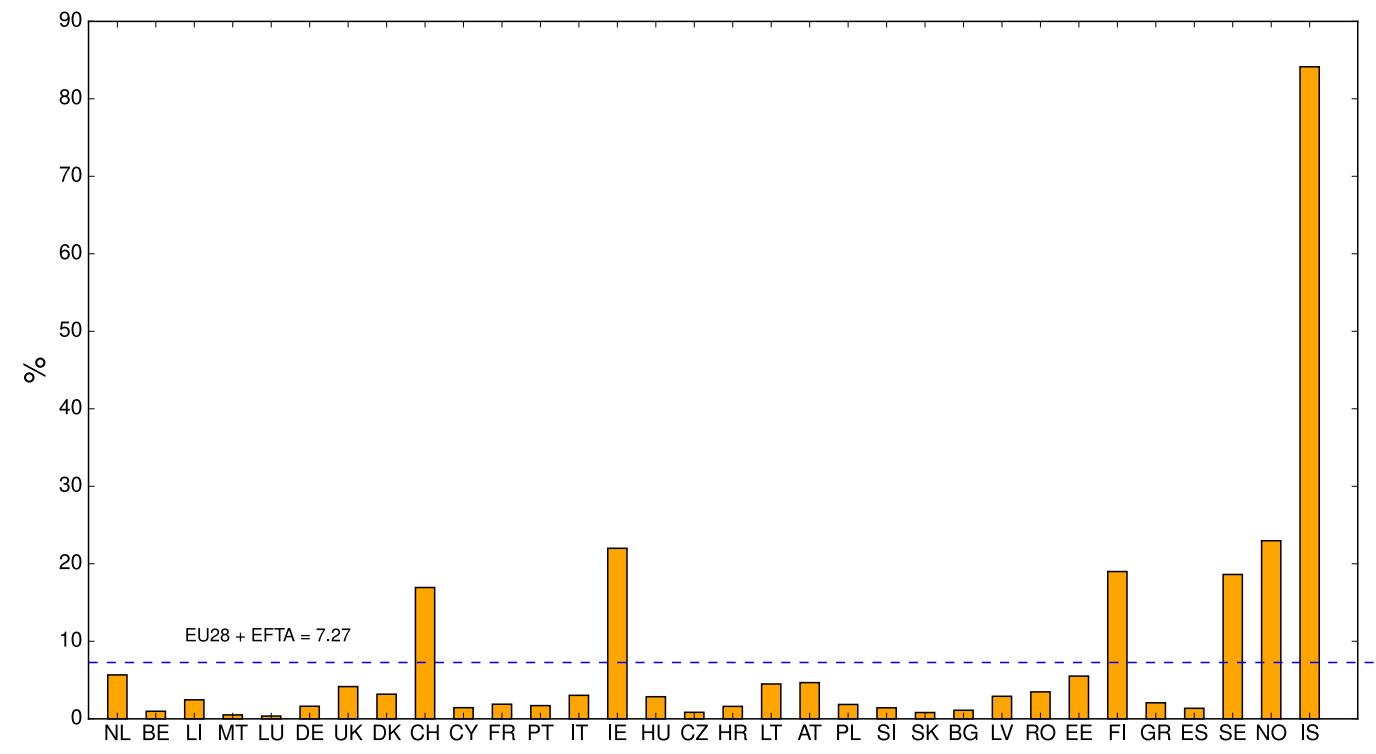

Figure B.2: Changes of WUP (in \%) values due to the exclusion of irreclaimable areas from the reporting units (countries).

Considering the relative changes (Fig. B.2), the WUP values excluding irreclaimable area increase considerably in the Scandinavian countries and Iceland $(84.15 \%)$. The northern parts of these countries are covered to a larger extent by mountains and glaciers, which in addition to the climate, makes these areas less favourable for the construction of settlement areas.

Similarly, the WUP values increased in all NUTS-2 regions as well when irreclaimable areas were excluded (Fig.B.3). The largest changes were observed for the Irish NUTS-2 region Border, Midland and Western (IE01, 34.57\%), the Aosta Valley (ITC2, 33.19\%) in Italy, and the Lake Geneva region (CH01, 33.85\%) in Switzerland. Twenty-five other NUTS- 2 were still showing an increase of urban sprawl between $10 \%$ and $28 \%$. For a table with a list of all values, consider the supplementary material.

For any particular country, the determination of such areas is possible in a more reliable and more detailed way. For example, the areas considered as not feasible for the construction of buildings in Switzerland have been identified by experts. They can be divided into two groups:

1. Areas not suitable for construction because of geo-physical conditions: lakes, rivers, glaciers, firns, rocks, and slopes steeper than $45^{\circ}$. 


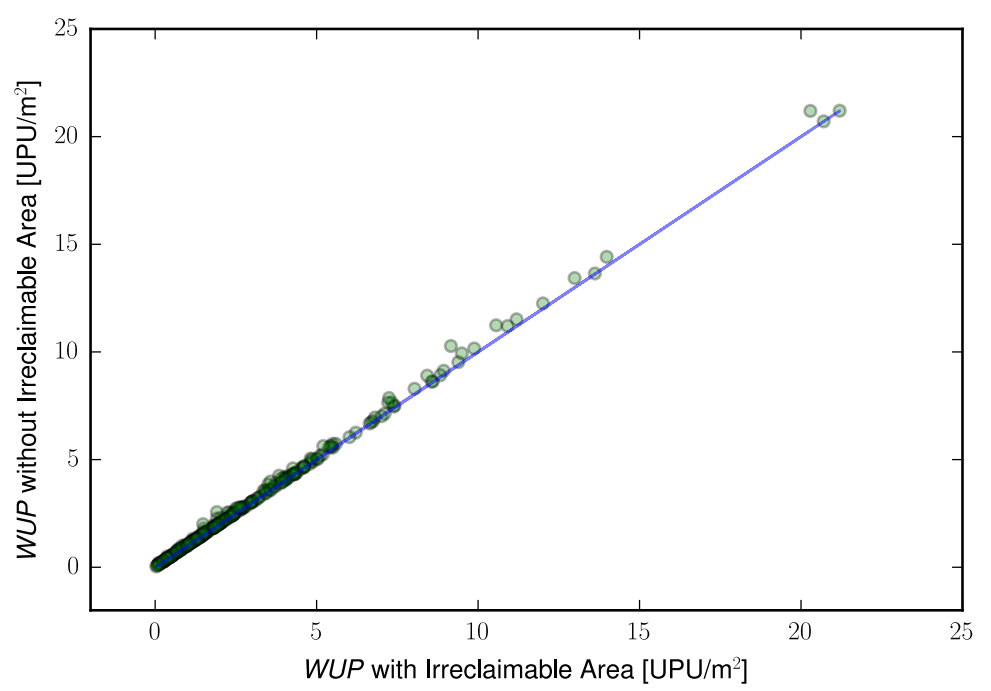

Figure B.3: WUP values with and without the consideration of irreclaimable areas at the NUTS-2 level. 2007, 2008 and 2010) possible delineations for Switzerland (Fig. B.4). land in 2010 is $2.47 \mathrm{UPU} / \mathrm{m}^{2}$. $\mathrm{UPU} / \mathrm{m}^{2} / 0.433=5.7 \mathrm{UPU} / \mathrm{m}^{2}$. $\mathrm{UPU} / \mathrm{m}^{2} / 0.301=8.21 \mathrm{UPU} / \mathrm{m}^{2}$.

2. Protected areas: Forests (Swiss Federal Act on Forest, protected since 1879), Swiss national park (protected since 1914), riverine meadows (Swiss Federal Act on the Protection of Nature and Cultural Heritage, Art. 18, protected since 1992), fens and raised bogs (Federal Constitution of the Swiss Confederation, Art.78.5, since 1987), dry grasslands and meadows (Verordnung ber den Schutz der Trockenwiesen und -weiden von nationaler Bedeutung, protected since 2010), and the UNESCO world heritage sites (UNESCO World Heritage Convention, protected in

For a given research question, different delineations of reporting units are possible. As an example, we show three

- The whole area of Switzerland is considered as the reporting unit $\left(\mathrm{RU}_{1}\right)$ (Fig. B.4 (A)). The $W U P_{1}$ for Switzer-

- Areas that are inappropriate for construction because of geo-physical conditions and forests are excluded from the area of Switzerland (Fig. B.4 (B)). The excluded areas cover 56.7\% of Switzerland. The resulting reporting unit $\left(\mathrm{RU}_{2}\right)$ therefore covers $43.3 \%$ of $\mathrm{RU}_{1}$. The value of $W U P$ in this case is: $W U P_{2}=W U P_{1} / 0.433=2.47$

- All areas that are inappropriate for construction because of geo-physical conditions and protection regulations (Fig. B.4 (C)) are excluded. In this case, the excluded areas cover $69.9 \%$ of Switzerland. The resulting reporting unit $\left(\mathrm{RU}_{3}\right)$ therefore covers $30.1 \%$ of $\mathrm{RU}_{1}$. The value of $W U P$ in this case is: $W U P_{3}=W U P_{1} / 0.301=2.47$ 


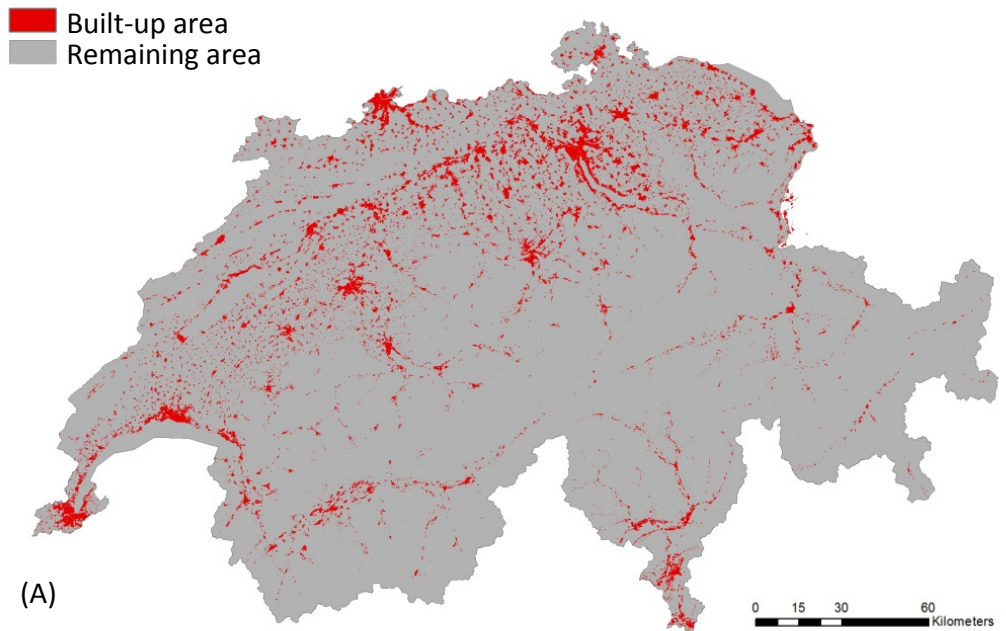

Built-up area

Excluded area

Remaining area
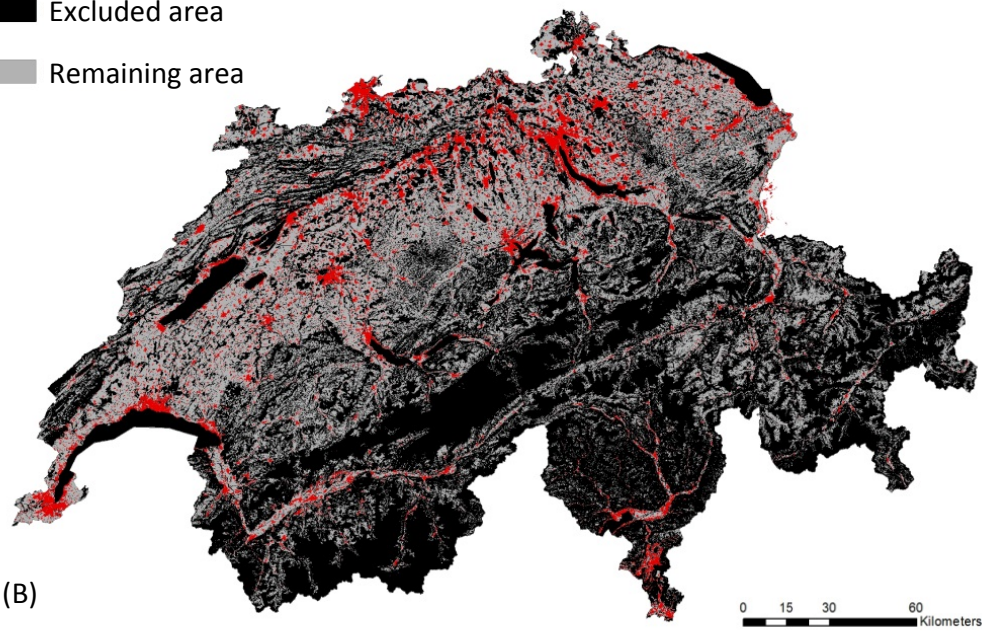

Built-up area

Excluded area

Remaining area

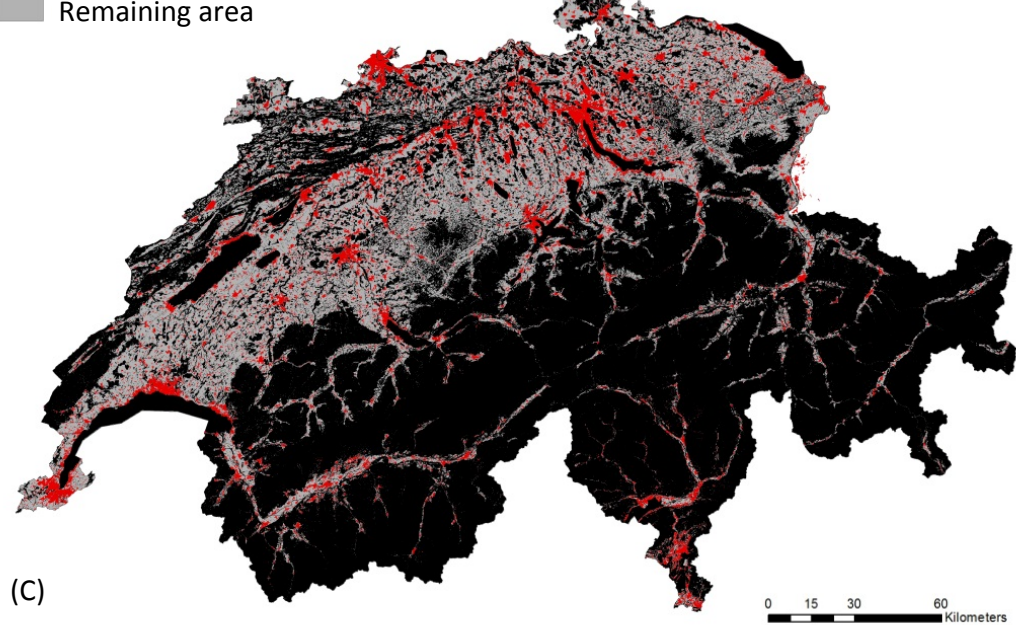

Figure B.4: Three options for the delineation of reporting units: The whole area of Switzerland is the reporting unit (A). Areas that are inappropriate for construction because of geo-physical conditions and forests are excluded from the reporting unit (B). All areas that are inappropriate for construction because of geo-physical conditions and protection are excluded from the reporting unit (C). 
Since various regions differ in the amount of area that is not suitable for construction, the comparison of such regions may be more appropriately done when these differences are excluded from the reporting units. This means that WUP provides the degree of urban sprawl of the landscape in relation to the area that is, in principle, potentially suitable for construction. For example, the degree of sprawl of a reporting unit that includes a major lake may be compared more appropriately to a reporting unit without a lake when the lake is excluded. The same is true for areas that are protected. However, this is not easily done in Europe because protection regulations differ considerably among European countries and data about them are difficult to obtain.

\section{Appendix C. Analysis of urban sprawl at a scale of 1 ha}

The scale of an urban sprawl analysis using the WUP metric depends only on the resolution of the necessary data sets about built-up areas and the number of inhabitants and jobs. In Switzerland, we obtained information about builtup areas from Swisstopo's digital landscape model swissTLM3D at a scale of 1:25,000 (for 2010). The swissTLM3D is a topographic landscape model that includes both natural and artificial landscape features in vector form. The swissTLM3D includes layers of settled areas, which were manually captured along their borders. Data on inhabitants and jobs were drawn from two different sources. Population data are from the census of 2010. Data regarding jobs were drawn from the federal business censuses of 2008. As an example of the results, we show the WUP 1-ha grid values for the canton of Zürich (Fig. C.1 (A); Schwick et al., (under revision). Zürich is the most populated canton in Switzerland with roughly 1.5 million inhabitants and covers an area of 1,729 $\mathrm{km}^{2}$ (Fig. C.1 (B)). Impressive findings about urban sprawl values at a very fine scale can be seen at the following locations:

- The city center of Zürich is highly populated and includes many working places. Therefore, the WUP values are very low.

- Very low WUP values are also found in the historical centers of small towns or villages. Here, the LUP is very low because of dense settlement.

- High to very high sprawl levels are found in suburban areas. These areas can be residential (areas with scenic views over the lake of Zürich with large lots and villas (c1), less densely used built-up areas with high $L U P$ (c2)), or industrial (c3).

- High sprawl levels are also found in areas with large transport infrastructure facilities like the airport (d1) or the switch yard (d2).

- Medium to low $W U P$ values are found in small villages and rural areas.

Analysis of sprawl at such a fine scale makes it possible to investigate sprawl down to the scale of neighborhoods and to separately investigate single types of sprawl (residential sprawl, touristic sprawl, industrial sprawl, etc.), which is not possible at the $1-\mathrm{km}^{2}$ scale. 


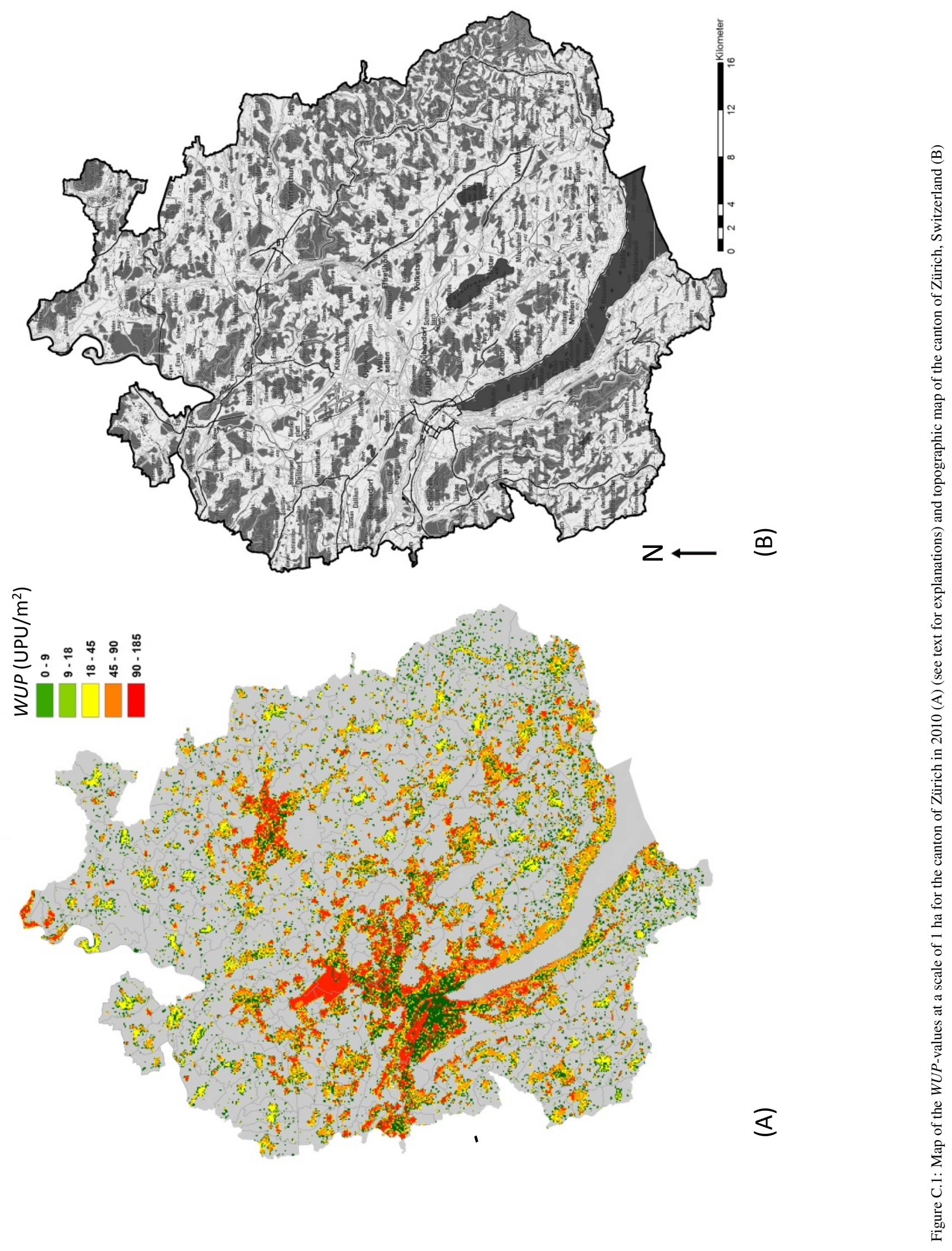

